\title{
QUALITY OF PUBLIC SPACES AND SUSTAINABLE URBAN DEVELOPMENT: SUCCESS AND FAILURES IN FIGHTING SOCIAL EXCLUSION
}

\author{
C. TRILLO \\ School of Built Environment, University of Salford, UK.
}

\begin{abstract}
Sustainable Urban Development embeds the three pillars of sustainability: environmental, social and economic. The European Commission position on Sustainable Urban Development reflects this concept, recommending an integrated approach paying attention to several intertwined factors, including the quality of public spaces. In European cities, poverty issues and exclusion are particularly acute. Inclusive growth is one of the main drivers of the Europe 2020 strategy, thus, it is expected that actions for fighting social exclusion are significant in deprived urban areas. However, in the EC approach still policies for social inclusion tend to remain relegated to the socio- economic sphere, with a weak link to the physical element as specific matter of concern. This paper aims at discussing the role played by the spatial quality of public spaces in supporting social integration, by focussing on a case study in Italy. More in details, the paper discusses the effects of public policies undertaken in the 1990s by the City of Reggio Calabria to reduce poverty for the Roma people, by displacing those inhabiting squalid and unhealthy camps to council housing in two neighbourhoods with a different quality of public spaces. In one area the displacement happened successfully, in the other, social issues plague the community. The paper aims at investigating the influence of the quality of public spaces on the displacement outcomes. The research methodology is mainly qualitative and is based on field work complemented by photo survey and interviews. The paper suggests that the spatial quality of the public spaces might have contributed to exacerbate social conflict and detachment in the unsuccessful case. It is therefore recommended to incorporate a significant component on the public space inclusive design in any socioeconomic intervention aimed at overcoming social exclusion.
\end{abstract}

Keywords: quality of public spaces, social exclusion, sustainable urban development.

\section{SOCIAL EXCLUSION, SUSTAINABLE URBAN DEVELOPMENT AND PUBLIC SPACES}

Europe 2020, the current strategy provided by the European Commission for the programming period 2014-2020, pays great attention to the issue of social exclusion, by considering inclusive growth a major strategic pillar along with a smart and a sustainable growth. In quantitative terms, the target set by the European Commission is to support 20 millions of people to come out of poverty and social exclusion by 2020. [1] This goal is tackled also through the European platform against Poverty and Social Exclusion, a tool that couples the Europe 2020 strategy by offering a broad range of solutions to achieve the inclusive growth goals. [2] European cities are strongly encouraged by the European Commission to adopt a framework for contributing to the achievement of a smart, inclusive and sustainable growth. In 2008, following the release of the Leipzig Charter, [3] the Reference Framework for 
European Sustainable Cities was launched, with the aim to provide European cities with an appropriate tool to make integrated sustainable urban development to happen. [4]

The "Leipzig Charter on Sustainable European Cities" [3] represents a milestone in the consolidation of the conceptual paradigm of Sustainable Urban Development (SUD), that stems from the 1990s Community Initiative Programmes URBAN I [5] and URBAN II [6] and has been elaborated through incremental steps. [7] According to the Leipzig Charter, Member States shared recommendations on, among others, putting forward the following actions: "creating and ensuring high-quality public spaces" (while) "making greater use of integrated urban development policy approaches" and "pursuing strategies for upgrading the physical environment" (while paying) "special attention ... to deprived neighbourhoods". Further actions to cope specifically with social exclusion in deprived neighbourhoods are also included, such as, "strengthening the local economy and local labour market policy" and supporting "proactive education and training policies for children and young people".

As part of the integrated strategy for SUD, public spaces are explicitly contemplated as an essential component of any balanced intervention. The European approach on SUD and on the importance of public spaces to support integrated sustainable development in cities reflects the consolidated body of literature, according to which consensus exists on the fact that SUD paradigm is based on a holistic concept, embedding the three pillars of sustainability: environmental, social and economic. [8,9] Fighting social exclusion and triggering SUD are intertwined policies, because interventions aimed to support social integration are particularly necessary in urban contexts. As highlighted in the document Cities of Tomorrow [10, iii] "More than two thirds of the European population live in urban areas. Cities are places where both problems emerge and solutions are found. They are fertile ground for science and technology, for culture and innovation, for individual and collective creativity, and for mitigating the impact of climate change. However, cities are also places where problems such as unemployment, segregation and poverty are concentrated". The following section sets the context for the connection between public spaces and social inclusion policies and introduce the case study within this conceptual frame.

\section{FIGHTING EXCLUSION: WHAT ROLE FOR PUBLIC SPACES?}

The importance of public spaces as they are designed and shaped may vary according to the perspective of the evaluator [11]; however, consolidated consensus exists in the literature on the high social value and potential for integration of public spaces. [12-19] Dines and Cattel [20] recognized that public realm offers opportunity for social encounter and therefore ethnic integration. Gaffikin et al. [21] explored the relationship between physical shape and social conflict in contested cities, even supporting the idea that manipulating spaces may have a social impact. Bollens [22, 103] discussed the key role played by materiality in supporting (or not) social integration. Regarding politically turbulent cities, he even stated that: "Urban policy shaping of materiality and space will not turn around a society that is splintered or unraveling. Urbanism can, however, create physical and psychological spaces that complement and encourage inter-group reconciliation, exploiting and building upon peace building opportunities when a city advances beyond a suspended state of ethnic division toward some greater array of spatial options." Moreover, consensus exists on the connection between quality of urban design and quality of public spaces. [16, 23].

Despite the magnitude of the problem of the social exclusion and although in the literature, it is recognized how public spaces, and in particular their physical component, are relevant in supporting effective integration, [22-25] still policy documents lack of attention on how to 
address spatial quality of public spaces in a consistent manner. For the reasons highlighted in the previous section, this gap may cause a failure in the attempt to achieve integrated SUD.

Innovative instruments such as Community Led Local Development (CLLD) and Territorial Integrated Investments (ITI), introduced by the European Commission in the current 2014-2020 programming period, are not likely to be supportive on this in themselves. Although in theory it is asserted that the two instruments are now available and "can be used to implement territorial strategies on the ground, linking the thematic objectives identified in the Partnership Agreements and Operational Programmes and the territorial dimension: CLLD (Article 32-35 of the Common Provisions Regulation) and Integrated Territorial Investments (Article 36 of the Common Provisions Regulation)", [26] in practice, because they are not specifically conceived for pursuing integrated urban regeneration, the integration they mention tends to remain relegated to the financial sphere, with a weak link to the physical element. Due to the nature of both CLLD and ITI, aimed at supporting integrated governance amongst different stakeholders and at allowing a better focus on the place specificity at the larger scale, it is unlikely that they would act as catalysts for effective integration at the neighbourhood scale without a proper support of specifically spatial-led and physical oriented instruments. Because public spaces play a key role in SUD and as the importance of design in quality of public spaces is recognized, physical quality should be incorporated within any integrated policy.

This paper aims at discussing the role played by the spatial quality of public spaces in supporting social integration, by focussing on a case study in Italy. More in details, the paper discusses the effects of public policies undertaken in the 1990s by the City of Reggio Calabria, to reduce poverty for Roma minorities, by displacing those inhabiting squalid and unhealthy camps to council housing with a very different quality of public spaces. Two neighbourhoods have been observed (Arghillà and Rione Marconi- Sbarre, see Fig. 1), where Roma people have been displaced. The research methodology is mainly qualitative and is based on extensive field work complemented by photo survey and interviews in the two neighbourhoods, where this displacement took place in two different ways, one more successful than the other.

More in details, social exclusion plagued Roma community in Reggio Calabria since the 1950s, when they used to gather particularly close to the streams. Disastrous floods in the 1970s affected Roma population and raised public attention on the issue of their exclusion. Consequent public policies of displacement of the Roma community to council housing were aimed at improving their conditions and overcoming a situation of extreme poverty. [27, 28] It has to be highlighted that Roma population is suffering high levels of poverty and exclusion in almost all the European countries, [29] thus, the European Commission is particularly seeking to address this issue across the whole Europe. [30, 31] In Reggio Calabria, at the end of the 1990s many Roma families were directed to the neighbourhood of Arghillà, while others were displaced to different areas, including Rione Marconi- Sbarre. A local NGO -Opera Nomadi- supported Roma population in getting council housing (interview with Opera Nomadi, 2016).

Rione Marconi - Sbarre area is located East of the Reggio Calabria city centre, while Arghillà is located in a suburban area in the Northern part, detached from the city centre. In both areas council housings were built according to the 167 Law -i.e., the National Law that gave the impulse to the construction of massive public estate neighbourhoods in Italy-. It is anticipated that currently, while in Rione Marconi- Sbarre no relevant issues seem to emerge in terms of social conflict, neither from the secondary data gathered, nor from the interviews, showing a high level of social integration between different communities (in particular, the 


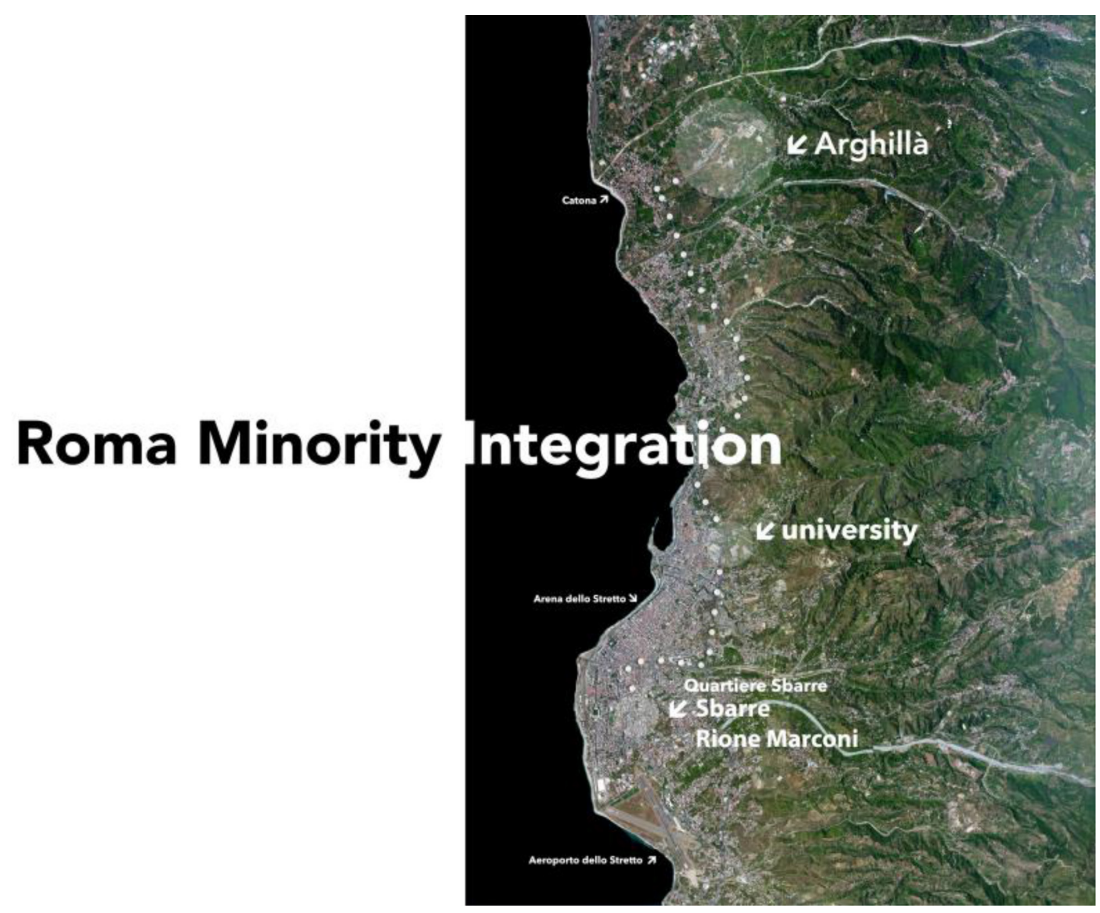

Figure 1: Case Studies Localization, Map Elaborated by A. Errigo, G. Minervino, Y. Ou, L. Starace (2016).

Roma community and the existing one), Arghillà results to be labelled as a ghetto, where the integration of different communities is not happening.

The research conducted suggests that the spatial quality of the public spaces contributed to exacerbate social conflict and detachment in the unsuccessful case (Arghillà). The following section discusses this issue throughout the analysis of the empirical data gathered.

\section{INVESTIGATING THE ROLE PLAYED BY PUBLIC SPACES IN SUPPORTING INTEGRATION}

Once defined the research question as how far public spaces influence successful policies aimed at fighting social exclusion, it was decided to investigate successful and unsuccessful integration intervention, in a similar context with different outcomes. The research methodology stemmed from the constructivist approach in social sciences and was mainly driven by the goal to unveil the embedded knowledge of the local actors on the matter of concerns -i.e. integration, quality of public services, quality of public spaces. The selection of the case studies was led by some preliminary interviews with key informants, that allowed the researchers to raise the question of what differences existed between two neighbourhoods interested in high level of Roma minorities displacement and showing different degrees of integration. More in depth, the preliminary interviews allowed to focus on the two areas of Arghillà and Rione Marconi-Sbarre areas within the city of Reggio Calabria (interviews with city planners at the City of Reggio Calabria, 2014). This initial research input was corroborated with secondary data gathering, including newspaper articles, e-magazines and further literature. 
All the sources converged towards highlighting the importance of the Roma integration issue in the two selected neighbourhoods.

The research design was aimed at relating the matter of concerns with the two purposely selected case studies, in order to find out what was working, and what was not working, in the two cases. The research methodology was mainly qualitative and was based, for both areas, on: (1) Analysis of secondary sources (literature, newspapers, articles, e-magazines); (2) Spatial analysis (grid pattern, public spaces layout, connectivity with the wider urban context); (3) Visual analysis (field work, photo survey); (4) Informal interviews with residents (taking not-recorded written notes of informal discussions with random local people during the field work); (5) Semi-structured interviews with key- informants (both key informants specifically involved in one of the two areas and key informants on more general issues of social integration in Reggio Calabria).

The field work benefitted from two sessions on research method run by the author at the International Doctorate on Urban Regeneration and Economic Development of the University Mediterranea of Reggio Calabria, Italy (Ph-D students involved in 2015: Biancuzzo, Cantafio, Cascella, Colombo, Mahmoud and Pronestì; in 2016: Errigo, Minervino, Ou, Starace). Visual analysis in both areas was conducted during multiple sessions of field work, including informal talking with local people. Semi-structured interviews were aimed at investigating the significance of the following factors in supporting social integration: (1) mixed use (2) connectivity (3) public facilities (4) socio-cultural activities. The four factors were drawn from the literature on the role of public spaces and urban design in supporting social integration. $[12,15,16,18,19]$ The interview structure followed the mentioned criteria, while the analysis was conducted by taking into account both the frequency of the recurrent concepts and the different values given to the main criteria by the interviewed. The visual survey of the public space conditions supported the discussion of the opinions gathered through the interviews, such as the physical/ social connectivity and the size and shape of the public spaces.

The visual analyses showed a substantial difference in the spatial quality of public spaces in the two cases. While Arghillà presents generous but disconnected open public spaces, lacking in defined edges (see Fig. 2), on the contrary, Rione Marconi- Sbarre area is characterized by a fine grain of streets, intertwined with some public open spaces whose boundaries are clearly defined by the surrounding built environment (see Fig. 3). In terms of community sense of ownership, while in Arghillà public plazas and streets appears abandoned and derelict and people reported feeling of insecurity and fear (interview with local people, 2015), in Rione Marconi- Sbarre playgrounds and public spaces are place where people gather and talk. Some local residents even reported that the community took the initiative to fence a small green open space for the security of children (informal interviews with local residents, 2015). In terms of services, the two neighbourhoods are very different. In Arghillà the main social aggregator is represented by the local parish, coupled by a centre for children run by a local volunteering association with enthusiasm and good results in a place made available by the City (interview with volunteers, 2016). In the area, there is a major attractor with a high potential in terms of tourism as well, that is, the Ecolandia Park (number 6 in Fig. 2). [32] This latter was built thanks to the URBAN program in the 1990s, and is located in a marvellous landscape frame on the Strait. It includes green open spaces, playgrounds, small buildings for workshops and small meetings and offers a broad range of didactic activities for children and leisure for adults. However, volunteers and social workers serving the park reported a lack of participation in the initiatives, in their opinion, because of the persisting stigma associated with the neighbourhood of Arghillà, not a pleasant place to spend free time for outsiders (interview with local volunteers, 2016). On the other 


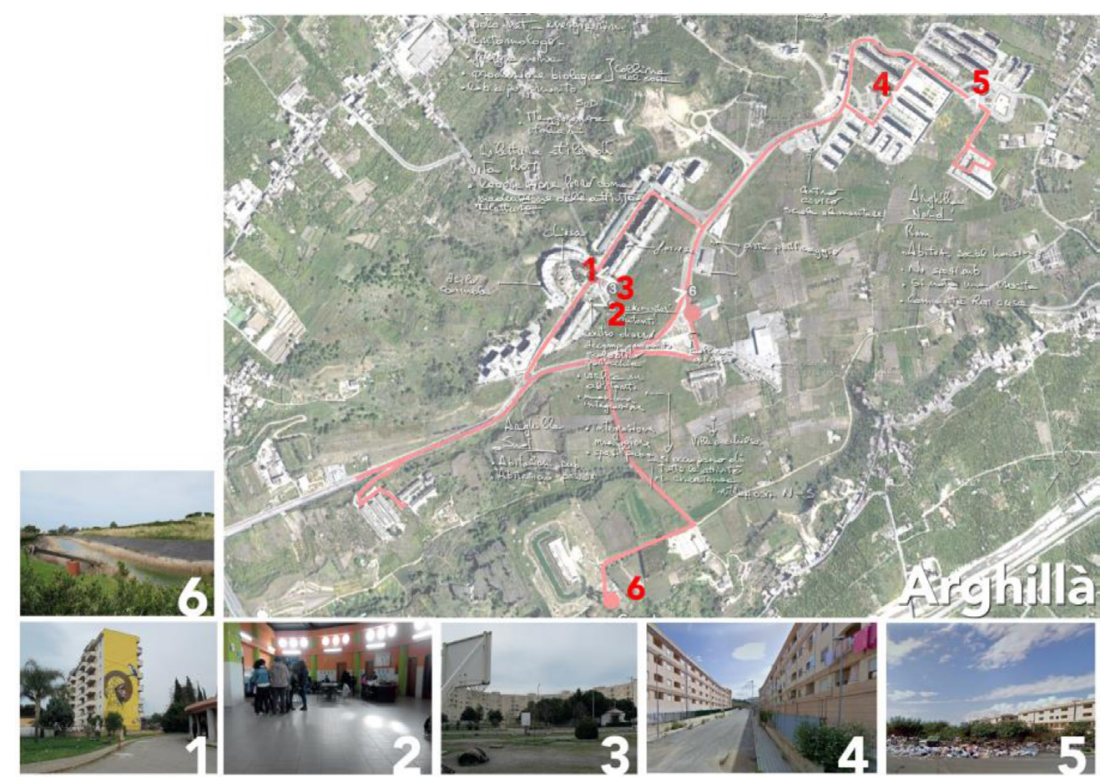

Figure 2: Visual survey of Arghillà (elaborated by Errigo, Minervino, Ou, Starace 2016).
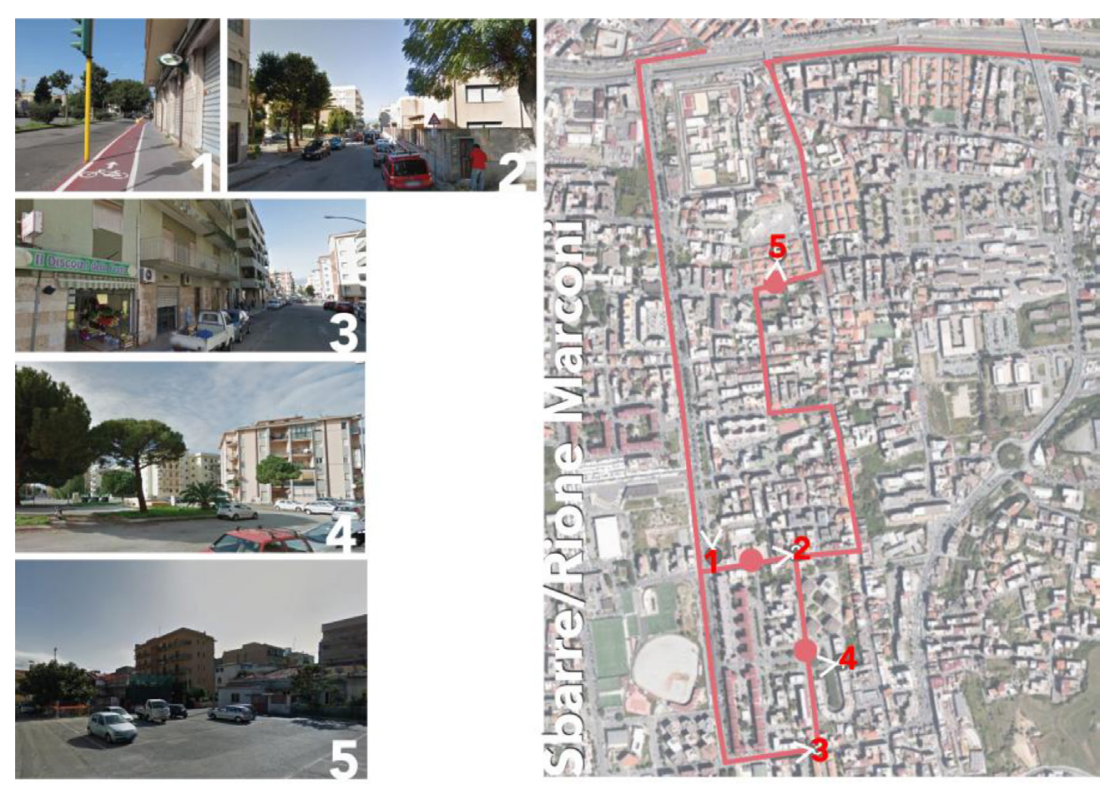

Figure 3: Visual survey of Rione Marconi-Sbarre (elaborated by Errigo, Minervino, Ou, Starace 2016).

side, the neighbourhood of Rione Marconi- Arghillà shows a level of services much higher (see Fig. 4). More in details, in the early childhood service, it seems that excellent results have been achieved (interviews with experts working in the early education services in the Rione Marconi, 2016; interview with public officers working at the Social Policies Department of the City of Reggio Calabria, 2016). 


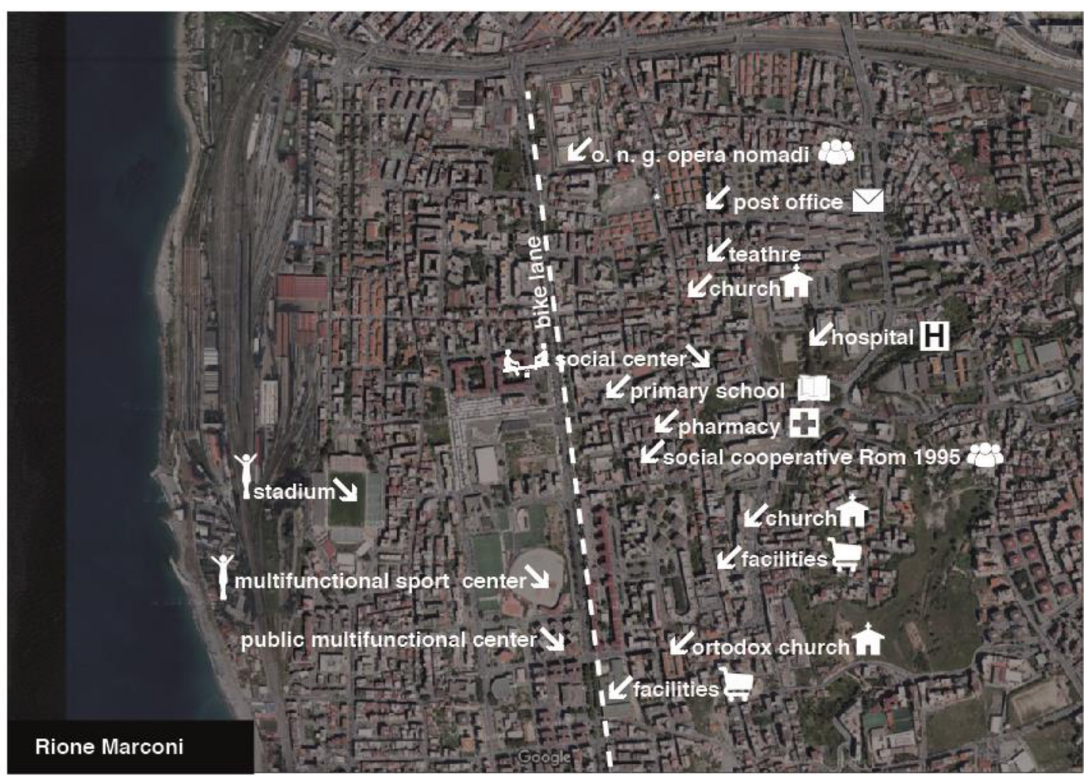

Figure 4: A survey of the public facilities of Rione Marconi-Sbarre (elaborated by Errigo, Minervino, Ou, Starace 2016).

\section{public spaces \\ integration \\ accessibility \\ public policy है \\ frequency analysis}

Figure 5: Frequency analysis from the interviews (elaborated by Errigo, Minervino, Ou, Starace 2016).

Interviews with local residents, informally conducted during the field work in both areas, showed a shared perception of a poor level of integration in Arghillà and a fair level of integration in Rione Marconi- Sbarre. Semi- structured interview analysis conducted through a frequency analysis (see Fig. 5) showed a shared consensus on the importance of the accessibility and management of public spaces. Consensus also existed on the importance of having 
these spaces available as precondition to make the community-led initiative viable (interview with Arghillà volunteers, 2016).

\section{CONCLUSIONS AND RECOMMENDATIONS}

Sustainable Urban Development, far from being an abstract concept, requires a high level of integration in public policies, including those aimed at overcoming social exclusion. However, though inclusive growth is one of the three pillars of the current 2020 European strategy, still a gap in the current approach exists on how to balance across different factors, including the physical one. This paper discussed the role played by the spatial quality of public spaces in supporting social integration, by focussing on a case study in Italy, suggesting that the physical component shouldn't be underestimated. In particular, by analysing the effects of public policies undertaken in the 1990s by the City of Reggio Calabria to reduce social exclusion and poverty of Roma minorities, the research sought to understand whether the different quality of public spaces might have influenced the different outcomes in the displacement process. Although it is not possible to conclude that public spaces positively influenced the successful case of integration, still a combination of factors can be observed in the unsuccessful case (Arghillà), that includes poor quality of public spaces and lack of connectivity of the neighbourhood with the wider urban context. By reflecting on the data collected, this paper suggests that the lack of spatial quality of the public spaces might have contributed to exacerbate social conflict and detachment in the unsuccessful case. Although it would be difficult to quantify the contribution of each factor in the overall (un)success, it is therefore recommended to incorporate a significant component of the public space inclusive design in any socio-economic intervention aimed at overcoming social exclusion in cities.

\section{REFERENCES}

[1] EC (European Commission). Europe 2020 Strategy. [online], available at: http:// ec.europa.eu/europe2020/index_en.htm [Retrieved March 2016].

[2] EC (European Commission). Employment, Social Affairs and Inclusion. European platform against poverty and social exclusion, available at: http://ec.europa.eu/social/main. jsp?catId=961 [Retrieved March 2016].

[3] EC (European Commission) Leipzig Charted on Sustainable European Cities. Final Draft 2 May 2007, available at: http://ec.europa.eu/regional_policy/archive/themes/urban/leipzig_charter.pdf. [Retrieved March 2016].

[4] RFSC, Reference Framework for European Sustainable Cities, www.rfsc.eu [Retrieved March 2016].

[5] EC (European Commission). Urban Community Initiative 1994 1999. http://ec.europa.eu/ regional_policy/archive/urban2/urban/initiative/src/frame1.htm [Retrieved March 2016].

[6] EC (European Commission). Urban II: Cities \& programmes. http://ec.europa.eu/ regional_policy/archive/urban2/towns_prog_en.htm [Retrieved March 2016].

[7] Colantonio, A. \& Dixon, T., Measuring Socially Sustainable Urban Regeneration in Europe, Oxford Institute for Sustainable Development (OISD), 2009.

[8] Tallon, A., Urban Regeneration in the UK, 2nd edn., Routledge: London, 2013.

[9] Jones, P. \& Evans, J., Urban Regeneration in the UK: Boom, Bust and Recovery, 2nd edn., Sage: London, 2013. http://dx.doi.org/10.4135/9781473915015

[10] EC (European Commission) Directorate General for Regional Policy. Cities of Tomorrow. Challenges, visions, ways forward; 2011, available at: http://ec.europa. 
eu/regional_policy/sources/docgener/studies/pdf/citiesoftomorrow/citiesoftomorrow_ final.pdf. [Retrieved March 2016]

[11] Carmona, M., De Magalhães, C. \& Edwards, M., Stakeholder views on value and urban design. Journal of Urban Design, 7(2), pp. 145-169, 2002.

http://dx.doi.org/10.1080/1357480022000012212

[12] Jacobs, J., The Death and Life of Great American Cities, Random House: New York, 1961.

[13] Putnam, R.D., Bowling alone: America's declining social capital. Journal of Democracy, 6(1), pp. 65-78, 1995.

http://dx.doi.org/10.1353/jod.1995.0002

[14] Putnam, R.D., Bowling Alone: The Collapse and Revival of American Community, Simon \& Schuster: New York, 2000.

[15] Calthorpe, P., The Next American Metropolis. Ecology, Community, and the American Dream, Princeton Architectural Press: New York, 1995.

[16] Gehl, J., Life Between Buildings: Using Public Space, 5th edn., Arkitektens Forlag: Copenhagen, 2001.

[17] Gehl, J. and Svarre, B., How to Study Public Life, Island Press: Washington D.C, 2013.

[18] Madanipour, A., Public and Private Spaces of the City, Routledge: London, 2003.

[19] Carmona, M., Heath, T., Oc, T. \& Tiesdell, S., Public Places - Urban Spaces, 2nd edn., Architectural Press: Amsterdam, London, 2010.

[20] Dines, N. \& Cattell, V., Public Space, Social Relations and Well-Being in East London, Policy Press: Bristol, 2006.

[21] Gaffikin, F., McEldowney, M. \& Sterret, K., Creating shared public space in contested city: the role of urban design. Journal of Urban Design, 15(4), pp. 493-513, 2010. http://dx.doi.org/10.1080/13574809.2010.502338

[22] Bollens, S., Intervening in politically turbulent cities: spaces, buildings, and boundaries. Journal of Urban Technology, 16(2), pp. 79-107, 2009. http://dx.doi.org/10.1080/10630730903278595

[23] Madanipour, A., Roles and challenges of urban design. Journal of Urban Design, 11(2), pp. 173-193, 2006.

http://dx.doi.org/10.1080/13574800600644035

[24] Madanipour, A., Social exclusion and space. In The City Reader, eds. R.T. LeGates \& F. Stout, Routledge: London, pp. 186-194, 2011.

[25] Bollens, S., Urban planning and intergroup conflict: confronting a fractured public interest. Journal of the American Planning Association, 68(1), pp. 22-42, 2002. http://dx.doi.org/10.1080/01944360208977189

[26] EC (European Commission) Integrated Territorial Investments; 2014, available at: http:// ec.europa.eu/regional_policy/sources/docgener/informat/2014/iti_en.pdf. [Retrieved March 2016].

[27] Cammarota, A. \& Tarsia, T., Reggio Calabria e Messina: tra mediazioni e conflitti. In Politiche Possibili. Abitare le città con i Rom e con i Sinti, ed. T. Vitale, Carocci Editore: Roma, pp. 87-94, 2009.

[28] Cammarota, A., Petronio, A., Tarsia, A. \& Marino, A.G., I Rom e l'abitare interculturale. Dai torrenti ai condomini, Franco Angeli: Milano, 2009.

[29] FRA (European Union Agency for Fundamental Rights) Housing conditions of Roma and Travelers in the European Union. Comparative Report, 2009, available at: fra.europa.eu [Retrieved March 2016] 
[30] McGarry, A., The dilemma of the European Union's Roma policy. Critical Social Policy, 32, pp. 126-36, 2012.

http://dx.doi.org/10.1177/0261018311425201

[31] Tremlett A. \& McGarry, A., Challenges facing Researchers on Roma Minorities in contemporary Europe: Notes towards a Research Program. ECMI Working Paper \#62, January 2013. available at: http://www.ecmi.de/uploads/tx_lfpubdb/Working Paper_62_Final.pdf. [Retrieved March 2016].

[32] Ecolandia. Il parco. [online], available at: http://www.parcoecolandia.it/ecosite/il-parco/ [Retrieved March 2016] 